\title{
Effects of flowering and production inducers in the Mexican lime (Citrus aurantifolia Swingle)
}

Ariza-Flores, Rafael $^{1}$; Michel-Aceves, Alejando Casimiro²; Gálvez-Marroquín, Luis Antonio³; Trujillo-García, David²; Avendaño-Arrazate, Carlos $\mathrm{H}^{4^{*}}$; Espinosa-Paz, Nestro ${ }^{5}$

${ }^{1}$ INIFAP Campo Experimental Iguala, Iguala de la Independencia, Gro., México; ${ }^{2}$ Colegio Superior Agropecuario del Estado de Guerrero, Iguala de la Independencia, Gro., México; ${ }^{3}$ INIFAP Campo Experimental Valles Centrales de Oaxaca, Santo Domingo Barrio Bajo, Etla, Oax., México; ${ }^{4}$ INIFAP, Campo Experimental Rosario izapa; 5 INIFAP Campo Experimental Centro de Chiapas, Ocozocoautla de Espinosa, Chis., México.

*Corresponding author: avendano.carlos@inifap.gob.mx

\begin{abstract}
Objective: To evaluate new hormonal and biostimulant products to induce flowering of Mexican lime (Citrus aurantifolia Swingle) for winter production at the state of Guerrero, Mexico.

Design/methodology/approach: Prohexadione calcium (PHD-Ca), cytokinins, paclobutrazol, biuretic urea, granulated urea $(46 \%)$ and a control were evaluated.

Results: There are differences between treatments for the number of flowers and number of fruits ( $\operatorname{Pr}>0.0411$ and 0.048$)$; regard the "number of flowers" variable, paclobutrazol, prohexadione calcium and granulated urea (46\%) stood out; while, prohexadione calcium, paclobutrazol and cytokinins favor the "number of fruits" variable. The yields show statistical differences ( $P r>0.0332)$ and the cytokinins and paclobutrazol stood out.
\end{abstract}

Findings/conclusions: The usage of cytokinins for induction and winter production of Mexican lime is suggested.

Keywords: Citrus, new inducers, biostimulants, phytohormones.

\section{INTRODUCCION}

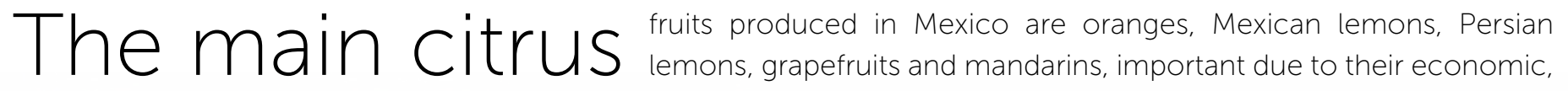
social and cultural impact. During 2018, the citrus fruits established area was 572,033 ha, which produced 7.8 million tons of fruit (SADER, 2019). For this reason, Mexico ranks fifth in world citrus production (FAOSTAT, 2019). The Mexican per capita consumption of lime is $14.0 \mathrm{~kg}$.

. (
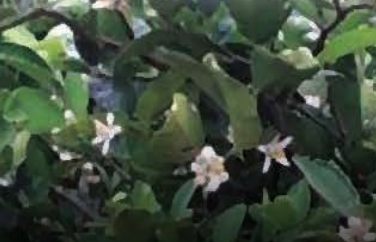

Agroproductividad: Vol. 13, Núm. 12, diciembre. 2020. pp: 19-24. Recibido: junio, 2020. Aceptado: noviembre, 2020
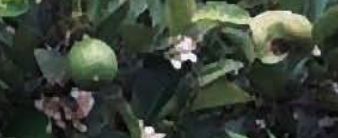
The environmental conditions at Guerrero, Colima, and Oaxaca, coastal areas in Mexico, are similar regard their production areas, and significantly differ from those at Michoacán, production areas; currently, these areas distribute at altitudes from 0 to $1000 \mathrm{~m}$, with 860 $\mathrm{mm}$ average annual rainfall and temperatures ranging between 25 and $28{ }^{\circ} \mathrm{C}$, in plains and hills, and soils with $\mathrm{pH}$ values between 5 and 7 . Their average obtained yields low (Ariza et al., 2004). Persian and Mexican limes produced in similar conditions reported average yields between 14.33 and $14.15 \mathrm{t} \mathrm{ha}^{-1}$ respectively (SADER, 2019). Their production is scarce from December to April, when it reaches its highest prices and their cultivation is profitable (Ariza et al., 2004). In this context, cultural practices can control the flowering season, a technique to improve the crop's profitability (Ruiz, 2001); such as pruning, girdling and the application of chemical substances (Ariza et al., 2004).

Knowledge on the reproductive biology of these plants has considerably increased in recent years, it is, therefore, necessary to understand more about the effects growth regulators have on citrus plants and their fruits since it is a complex and critical phenomenon, which depend on external and internal factors of the plants (Iglesias et al., 2007). Some studies mention the physiological effects of flowering induction in citrus fruits, such as hydric stress, pruning and girdling with periodic urea and Biofol applications (Lovatt et al., 1988; Ariza et al., 2004); as well as applying biostimulants, such as urea and Biofol in Mexican lime (Ariza et al., 2015) and Persian lime (Ambriz et al., 2018).

The applications of chemical substances favor flowering induction, a widely practiced agronomic activity (Ruiz, 2001). Authors such as Lugo et al. (2009) have reported that naphthaleneacetic acid application favors flowering at Morelos, Mexico, therefore this product's effect requires evaluation at different production times. Ariza et al. (2015) mention that a 4\% urea application favors flowering in Mexican lime. The harvest seasonality continues to prevail in the production areas from May to September, so their prices are low. Because of it, there is an increasing interest in new alternatives to produce flowers and fruits during the low production seasons. This situation occurs in Oaxaca and Guerrero states, where fruits commercialization during that period is difficult due to high production, to such a degree that exports and consequently assets decreased. The objective here was to assess the effects of new inducers and growth regulators on flowering induction of Mexican lemons, to increase productivity and competitiveness of production and quality of their fruits during winter

\section{MATERIALS AND METHODS}

Location and description of the study area. The test took place at Los Playones, Acapulco de Juárez, Guerrero, Mexico (km 7.0 scenic highway La Venta to Acapulco Diamante). The plantation is five years old. On it, trees are set $6 \mathrm{~m}$ between rows and $4 \mathrm{~m}$ between plants within rows and 417 plants per hectare density. The assessed products, doses and application methods are listed in Table 1. Their application occurred during the second quarter of September during the rainy season onset.

The trees were pruned by removing $30 \mathrm{~cm}$ from the treetop canopy. To apply the evaluated chemical substances, commercial adherent was used in doses of $1.5 \mathrm{ml} \mathrm{L}^{-1}$ of water

Agronomic management. The evaluated Mexican lime orchard was chemical fertilized with 120-60-60 $(\mathrm{N}-\mathrm{P}-\mathrm{K})$; Polychel multi was applied to the foliage in a $3 \mathrm{~L} \mathrm{ha}^{-1}$ dosage. Also, imidacloprid + cyfluthrin (300 $\left.\mathrm{ml} \mathrm{ha}{ }^{-1}\right)$, azadirachtin + citroline $\left(250 \mathrm{ml} \mathrm{ha}^{-1}\right)$ and

Table 1. Evaluated products, doses and times of applications to induce flowering in Citrus aurantifolia Swingle during the higher profitability season at Los Playones, Acapulco de Juárez, Guerro, Mexico.

\begin{tabular}{l|l|l|c}
\multicolumn{1}{c|}{ Product } & \multicolumn{1}{c|}{ Concentration } & \multicolumn{1}{c}{ Application Method } & $\begin{array}{c}\text { Evaluation application } \\
\text { periods (days) }\end{array}$ \\
\hline Citocininas (4000 ppm) & $2.4 \mathrm{~mL} \mathrm{~L}^{-1}$ water & Sprinkled to foliage & 0,15 and 30 \\
\hline Prohexadiona de calcio & $1.5 \mathrm{~g} \mathrm{~L}^{-1}$ water & To foliage & 0 and 30 \\
\hline Urea 46\% & $7.5 \mathrm{~g} \mathrm{~L}^{-1}$ water & To foliage & 0 \\
\hline Urea biurética 44\% & $1.2 \mathrm{~g} \mathrm{~L}^{-1}$ agua & To foliage & 0 and 30 \\
\hline Paclobutrazol $1 \%$ & $1.5 \mathrm{~mL} \mathrm{~L}^{-1}$ agua & Drained at the base of the stem or to the foliage & 0 \\
\hline Control & No aplication & & 0
\end{tabular}

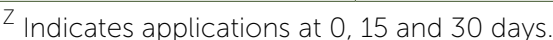


mineral oil (2 L ha-1) were applied for fruit plow mite control (Phyllocoptruta oleivora), insects such as aphids (Aphys gossypi and A. spiraecola) and diaphorina (Diaphorina citri Kuwayama). The presence of stem-end rot (Lasiodiplodia sp.) was controlled with matalaxyl + chlorothalonil (450 g) in 200 $\mathrm{L}^{-1}$ of water. The orchard was irrigated with a micro-sprinkler system, at a 100 to $120 \mathrm{~L} \mathrm{~d}^{-1}$ rate.

Evaluated variables. The effect of the treatments on the Mexican lime trees was evaluated at a $3.0 \mathrm{~m}$ height and $3.0 \mathrm{~m}$ within the tree crown diameter, as well as the number of flowers and fruits with "marble" size in selected branches of $75 \mathrm{~cm}$ length at $1.6 \mathrm{~m}$ in height from ground level, at each cardinal point in the tree. These evaluations were carried out every fifteen days, after treatment application, from October to December 2011. The fruit yield per tree was determined from the harvests during January and February, obtained from the total product weight of each tree with a 10 kg capacity mechanical scale, assessed every month and determined as $\mathrm{kg} \mathrm{ha}^{-1}$. A randomized complete block design was used, with five repetitions, a tree as an experimental unit. The statistical analysis was performed in the Statistical Analysis System (Anonymous, 2015) version 9.3 software, for means separation the Tukey test at $0.05 \%$ probability of error.

\section{RESULTS AND DISCUSSION}

The analysis of variance (ANOVA) for the numbers of flowers (Table 2 ) showed differences $(P \leq 0.05)$, between sampling dates and products applied for the flowering induction.

The number of registered flowers with paclobutrazol was statistically similar to those produced in control trees and most of the treatments, except for biuret urea, which was higher (Figure 1). It should be noted that the number of flowers produced in the control trees was statistically equal to the number of flowers produced in all treatments (Figure 1).

To assess the effects, the treatments had on the number of flowers, the sum of the sampling dates was made. For the October 11, 2018 sampling, the treatment effects were already shown. Overall, paclobutrazol and prohexadione
Table 2. Analysis of variance (ANOVA) of the number of flowers and number of fruits regard the flowering induction treatments (Citrus aurantifolia Swingle).

\begin{tabular}{l|c|c|c|c}
\multirow{2}{*}{ Variation source } & \multicolumn{2}{|c|}{ Number of flowers } & \multicolumn{2}{c}{ Number of fruits regard } \\
\cline { 2 - 5 } & Fc & P $>$ F & FC & P $>$ F \\
\hline Model & 2.16 & 0.0006 & 1.25 & 0.047 \\
\hline Sampling date (A) & 6.51 & 0.0001 & 1.61 & 0.037 \\
\hline Treatments (B) & 2.6 & 0.0411 & 1.57 & 0.028 \\
\hline
\end{tabular}

calcium stood out (Figure 2). Flowering in plants is shown in Figure 3. The Figure 2 shows the numerical superiority of the accumulated flowers during the sampling dates, achieved with paclobutrazol, followed by prohexadione calcium, compared with trees treated with granulated urea, cytokinins and the control.

Flowering relates to the summer season, not to the physiological age of the shoot, so that the Mexican lime flowers are in its lateral shoots (Hittalmani, 1977), while in Persian lime occurs in the terminal shoots (Hittalmani et al., 1977). Naturally, flowering in Mexican limes peaks

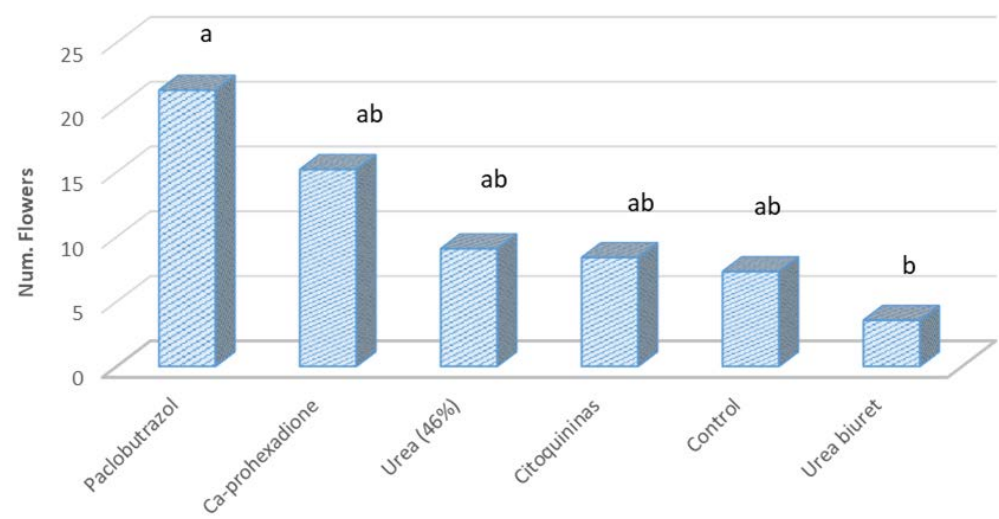

Figure 1. Effects of flowering inducing products. Treatments with the same letter are statistically equal (Tukey, $\alpha \leq 0.05$ ) and DMS $=16.25$.

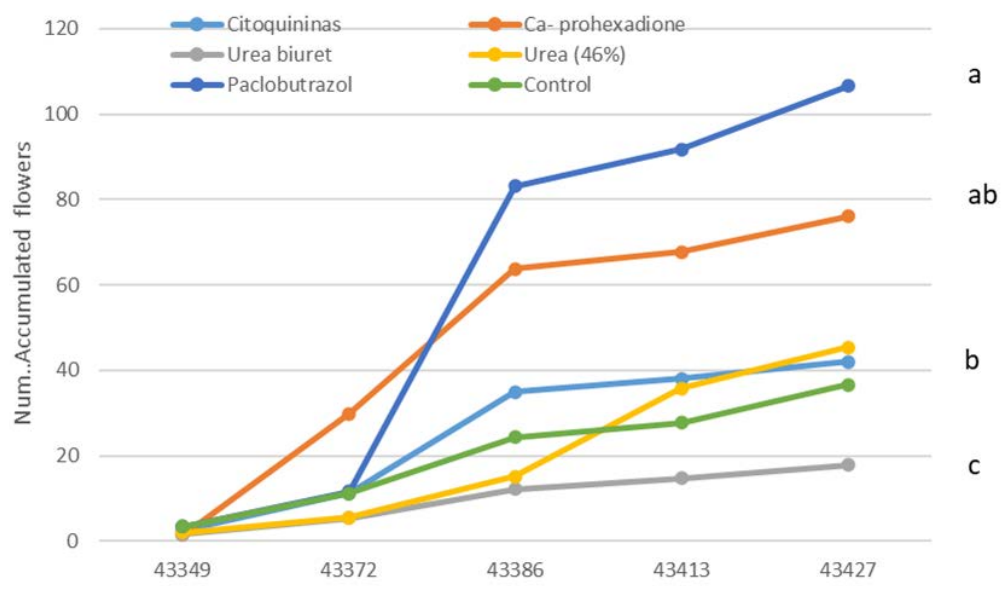

Figure 2. Number of flowers accumulated per tree (Citrus aurantifolia Swingle) for the three evaluation dates. Treatments with the same letter are statistically equal with the mean comparison test (Tukey, $\alpha \leq 0.05$ ) and a DMS $=16.25$. 

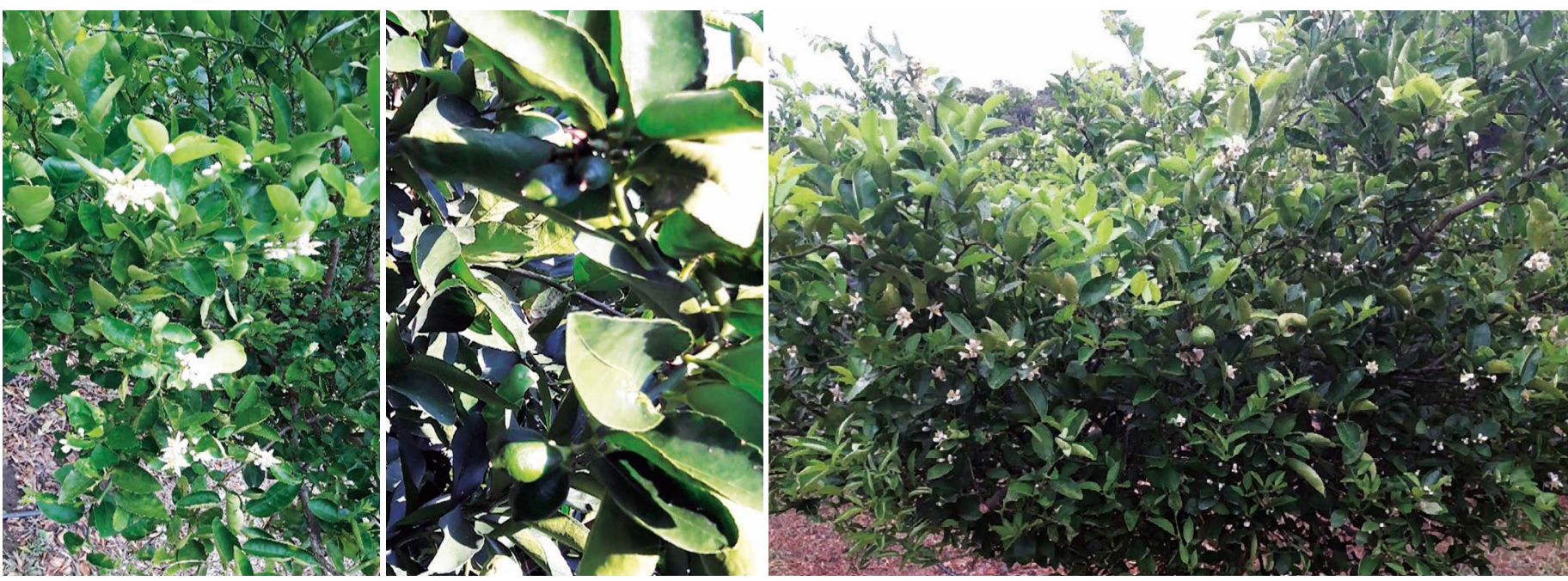

Figure 3. Induction to flowering and fruits in Citrus aurantifolia Swingle with prohexadione calcium.

during May and June (Ariza et al., 2004). However, with flowering inducers such as urea (46\%), their maximum peak is obtained by December (Ariza et al., 2015), in some instances, register two flowering flows, from December to January and from July to August (Athani et al., 1998), as shown in a study with a similar trend at the end of November. Tripathi and Dhakai (2005) applied paclobutrazol in C. aurantifolia during the second half of July and a flowering induction response was obtained 70 d later; which does not coincide with the test, given that at $50 \mathrm{~d}$ flowering increased in acid lime.

Some studies in 'Persian' lime, record that pruning + urea + ringing and pruning + Biofo $^{\circledR}+$ ringing in September quantified an average of 38 and 28 flowers each, which presented between 80 and $50 \%$ more flowers respect the other treatments (Ambriz et al., 2018). The application of urea + light pruning in Mexican lime and 'Persian' lime trees significantly favors flowering, while the application of urea and Biofol ${ }^{\circledR}$ favors higher flower production during winter (Ariza et al., 2004, 2015; Almaguer et al., 2011). The flowering increase is due to urea to ammonium conversion, which reduces growth because of the ethylene synthesis which induces flowering (Lovatt et al., 1988).

The results here presented were higher than those recorded by Ariza et al. (2015), given that in that study 6\% urea and Biofol treatments applied to Mexican lemon stood out. Ambriz et al. (2018) report that $6 \%$ urea plus pruning more ringed and pruning plus Biofol plus ringed applied in Persian lime, induced higher flowering and fruiting.
Therefore, this study has shown satisfactory results in the field. The same applies to the number of fruits.

The analysis of variance (ANOVA) for the number of fruits (Table 2) showed differences $(P \leq 0.05)$ between treatments. With the difference that the trees treated with prohexadione calcium showed a higher number of fruits, followed by the paclobutrazol treatment compared to the control trees (Figure 4). In such a way, the differences between treatments are appreciated in Figure 5. Mahalle et al. (2010) report with the application of cycocel at $1000 \mathrm{mg} \mathrm{kg}^{-1}$ flowering of the acid lime in August, in addition to a greater number of fruits during September and October. This can vary between production regions, as it occurs in the Coast of Guerrero state. Devi et al. (2011) reported a higher number of fruits with paclobutrazol. Likewise, this trial shows a greater

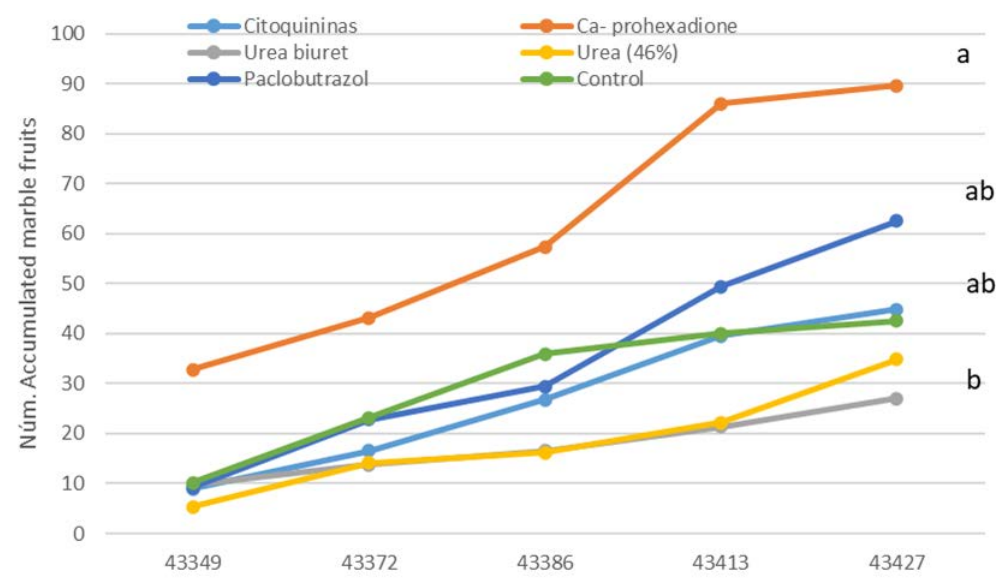

Figure 4. Effect of flowering inducers on the number of accumulated marble fruits of (Citrus aurantifolia Swingle). Treatments with the same letter are statistically equal with the mean comparison test (Tukey, $\alpha \leq 0.05$ ) and a DMS $=28.30$. 


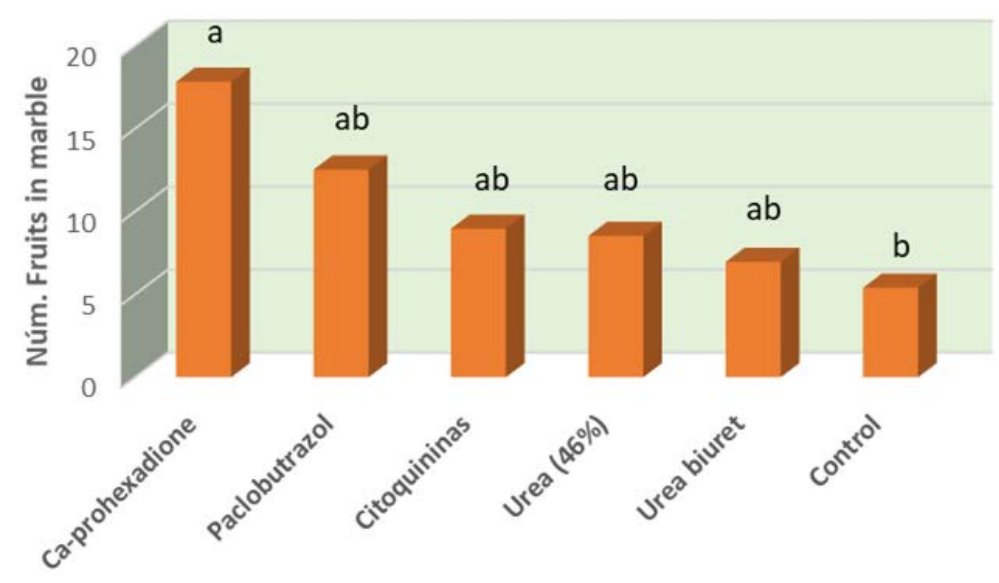

Figure 5. Effects of flowering inducing products on Citrus aurantifolia Swingle. Treatments with the same letter are statistically similar (Tukey, $\alpha \leq 0.05$ DMS $=11.873$ ).

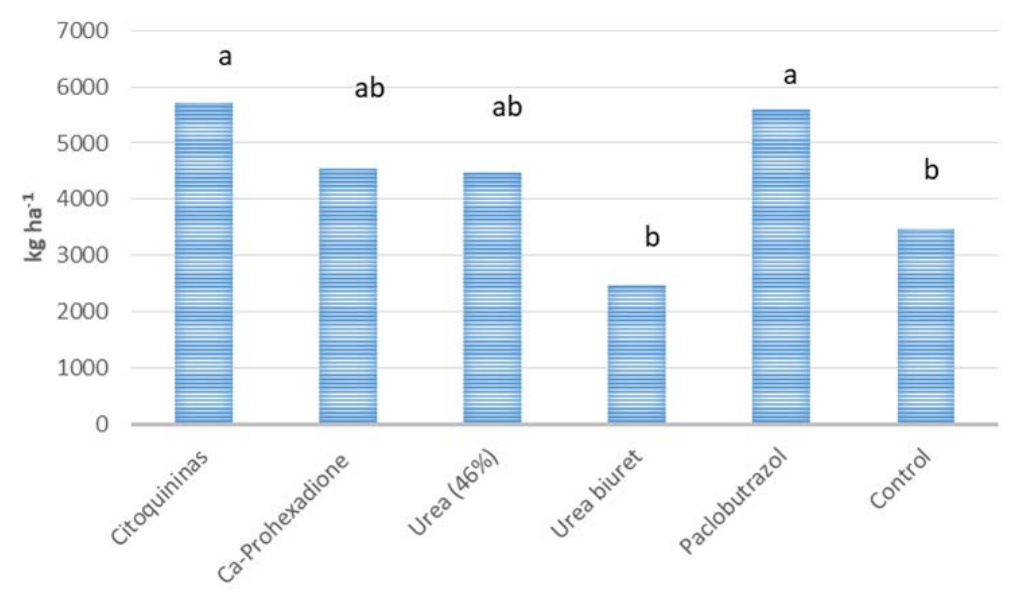

Figure 6. Effects of flowering inducers on yield $\left(\mathrm{kg} \mathrm{ha}^{-1}\right)$ of Mexican lime (Citrus aurantifolia Swingle). Treatments with the same letter are statistically similar (Tukey, $\alpha \leq 0.05$, DMS $=2254$ )

number of fruits with prohexadione calcium, with 17 fruits on average and 92 accumulated fruits, which coincides with those obtained by Devi et al. (2011), followed by paclobutrazol, cytokinins and the rest of the treatments, during the sampling period.
Prohexadione calcium shows effects on flowering induction and production in apples (Kiessling et al., 2008) and oranges (Garner et al., 2010). In Mexican lime it has satisfactory shown results; however, they are not similar to those reported by Ariza et al. (2015), since Biofol ${ }^{\circledR}$ and granulated urea showed excellent fruit production in acid limes.

Regard their yield, registered differences between treatments ( $\alpha \geq 0.05$ ) with paclobutrazol and cytokinins had a production of 5.8 and 5.6 t ha ${ }^{-1}$, respectively; followed by prohexadione calcium and granulated urea, while the lowest values were with biuret urea and the control (Figure 5).

In Mexico, the national yield average is $14 \mathrm{t} \mathrm{ha}^{-1}$, although in some states such as Yucatán and Colima yields are $20 \mathrm{tha}^{-1}$. In this study, only the yield obtained in the harvest months of January to April was assessed, which is low, but shows a higher trend than that of the granulated urea biostimulant. With the application of Biofol ${ }^{\circledR}$ and granulated urea biostimulants, the flowering and production of Mexican lime is induced, yield was twice as high during the same period (Ariza et al., 2015) and in 'Persian' lime with granulated urea (Almaguer et al., 2011). Flowering biostimulants do not generate wear for plants (Ariza et al., 2015), as recorded with cultural practices such as girdling (Ambriz et al., 2018). Paclobutrazol at $2.0 \mathrm{ml} \mathrm{L}^{-1}$ was not effective in Mexican lime (Ariza et al., 2015); however, this trial showed a better result, since the application formation drained at the base of the stem produced satisfactory results.
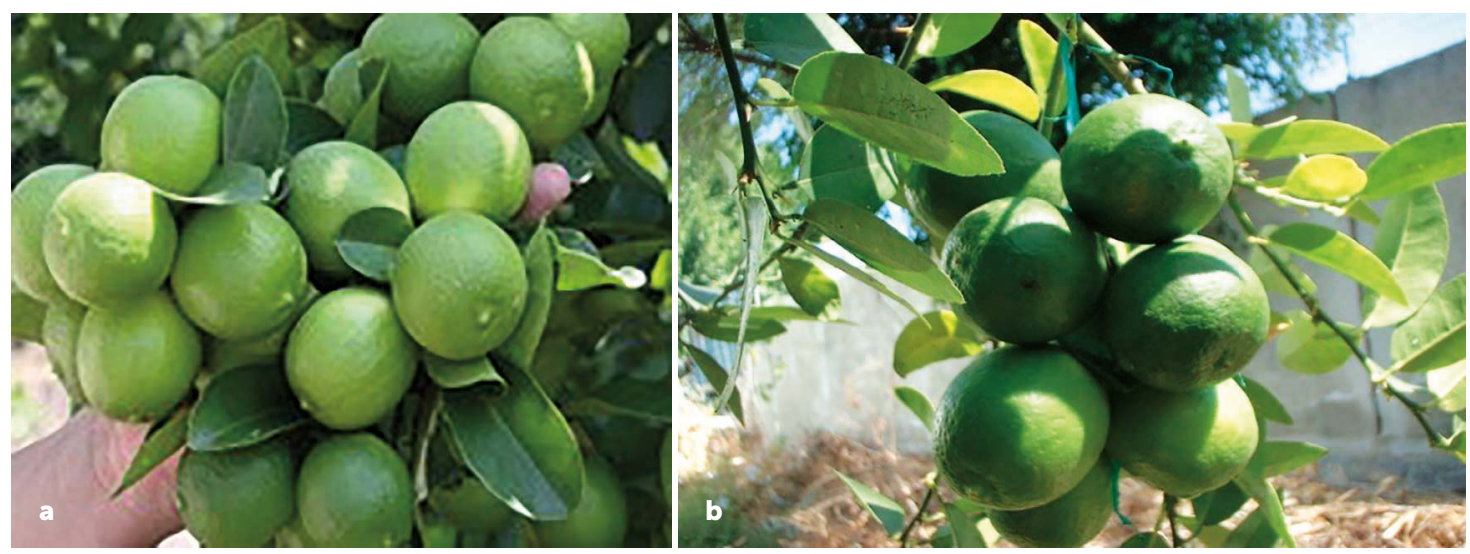

Figure 7. Response of flowering inductors for production of Mexican lime (Citrus aurantifolia Swingle) in Guerrero, Mexico. a. Cytokinins, b. Calcium prohexadione. 


\section{CONCLUSIONS}

With the biostimulant products of prohexadione calcium, paclobutrazol and cytokinins, flowering is induced and has effects on the formation of fruits. Cytokinins and paclobutrazol showed high yields and favored winter production. For this reason, they outperformed granulated urea in acid lime production.

\section{REFERENCES}

Almaguer, G.A., J.R. Espinoza, J. L. Quiroz G. (2011). Desfasamiento de cosecha de limón persa. Revista Chapingo Serie Horticultura, 17: 197-205

Ambriz, C. R., R. Ariza, F., I. Alia T., A. Michel A., A. Barrios A., M.A. Otero S. (2018). Efecto del anillado y bioestimulantes en la floración, producción y calidad de lima Persa (Citrus latifolia Tan.) en invierno. Revista Mexicana de Ciencias Agrícolas, Vol. $9(4): 711-722$

Anónimo. (2015). Statistical Analysis System Versión 9.3 para Windows (español). SAS Institute Inc. NC. Estados Unidos.

Ariza, F. R., R. Cruzaley S., E. Vázquez G., A. Barrios A., Alarcón, N. C. (2004). Efecto de las labores culturales en la producción y calidad del limón mexicano de invierno. Revista Fitotecnia Mexicana, 27(Especial 1):73-76.

Ariza, F. R., A. Barrios, A., M. Herrera G., F. Barbosa M., A. C. Michel A., M.A. Otero S., Alia T. I. (2015). Fitohormonas y bioestimulantes para floración, producción y calidad de lima mexicana de invierno. Revista Mexicana de Ciencias Agrícolas, 6(7):1653-1666.

Athani, S. I., N. C. Hulamani, Patil, M. P. (1998). FLowering and fruitset behaviour of kagzi lime strains. Adv. Agric. Res., 9:151-153.

Devi, H. L., S. K. Sarkar, L. Dhanabati, Majhi D. (2011). Flushing - flowering behavior and regulation in acid lime - Acritical review and research interventions. Journal of Crop and Weed 7(2):87-90.

FAOSTAT, (2019). Food and Agricultural Organization of the United Nations. Crops statistics data. http://www.fao.org/faostat/ en/\#data/QC (Consulta Septiembre 12, 2019).

Garner, L.C.; Y. Zheng; T. Khuong; Lovatt, C.J. (2010). Prohexadionecalcium affects shoot growth of evergreen subtropical woody perennials differently than deciduous temperate zone woody perennials - Is it a case of apples and oranges. Acta Horticulturae, 884:249-256.

Hittalmani, S. V. (1977). Studies on growth and fruiting in kagzi (Citrus aurantifolia Swingle) and Tahiti (Citrus latifolia Tanaka) limes. Mysore J. Agric. Sci., 11:113-116

Hittalmani, S. V., M. M. Rao, Bojappa, K. M. (1977). Studies on the parameters of flowering in the kagzi and Tahiti limes kin North Kamarata. Punjab Hort. J., 17:97-103.

Iglesias, D.J., M. Cercós, J.M. Colmenero F., M.A. Naranjo, G. Ríos, E. Carrera, O. Ruiz R., I. Llizo, R. Morillon, F.R. Tadeo, Talon, M. (2007). Physiology of citrus fruiting. Brazilian Journal of Plant Physiology, 19(4):1-30.

Kiessling, D. C. M., J. E. Magaña M., A. Segovia L., A. J. Obando R., y V. H. Villareal R. (2008). Prohexadiona de calcio como regulador de crecimiento en el manzano (Malus domestica Borkh.) "Golden Delicious". Ciudad Cuauhtémoc, Chihuahua, México. Tecno Ciencia Chihuahua., 1:7-12.

Lovatt, C., Y. Zheng, Hake, K. (1988). Demostration of a change in nitrogen metabolism influencing flower initation in citrus". Israel Journal of Botany, 37: 19: 181-188.

Lugo, A. A.; R. Ariza, F.; I. Alia T.; R. Ambriz C.; V. López M. 2009. Manejo Agronómico para la producción de limón persa en el estado de Morelos. INIFAP-SAGARPA. Folleto para Productor Núm. 48. $27 \mathrm{p}$.

Mahalle, S. S., H. V. Ingle, Sable, P. B. (2010). Influence of plant growth regulators and chemicals on yield and quality of Hasta bahar in acid lime. Green Farm., 1:285-287.

Ruiz, S. F.; I. Criztina L.; P. Roberto C. C. (2001). Efeito do ácido giberélico (AG3) nafloracáo e producao da lima ácida 'Tahiti' (Citrus latifolia Tan.). Revista Brasileira de Fruticultura, 23: $504-$ 509.

SADER, (2019). Anuarios estadísticos de la producción agrícola. Servicio de Información Agroalimentaria y Pesquera (SIAP). Secretaría de Agricultura, Ganadería, Desarrollo Rural, Pesca y Alimentación. México. URL: http://infosiap.siap.gob.mx/aagricola_siap_gb/ icultivo/index.jsp. (Fecha de consulta: septiembre 2, 2019).

Tripathi, K. M., Dhakai, D. D. (2005). Effect of paclobutrazol on offseason flower induction in acid lime (Citrus aurantifolia Swingle)land races under Chitwan condition. J. Inst. Agric. Anim. Sci., 26:87-92.

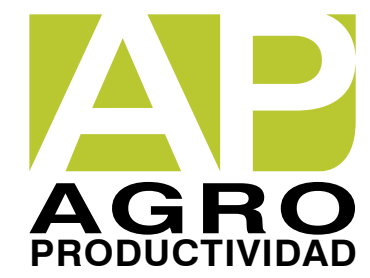

